\title{
Effects of Heavy Metals Pollution in Soil and Plant in the Industrial Area, West ALGERIA
}

\author{
Kebir Tahar* and Bouhadjera Keltoum \\ Inorganique Chemistry and Environmental laboratory (ICEL), Department of Chemistry, Faculty of Sciences, \\ University of Tlemcen, 13000 Tlemcen, Algeria. *E-mail: kebir_tahar@yahoo.fr \\ (Received August 7, 2011; Accepted October 22, 2011)
}

\begin{abstract}
Alzinc is a ursine situated in the Ghazaouet town western part of the republic of Algeria. The purpose of this study was to determine the degree of contamination which soil and plants are burdened with some heavy metals: $\mathrm{Pb}, \mathrm{Zn}, \mathrm{Ni}$, $\mathrm{Cu}, \mathrm{Cd}, \mathrm{Mn}, \mathrm{Cr}, \mathrm{Fe}$ and $\mathrm{As}$, then the accumulation of heavy metals in the soil and plant adjacent of area the alzinc ursine was detected and the interdependence of pollution among all three regions of the environment determined .This paper analyzes the heavy metal contents within a 2-years period in the soil and plants at the beginning of the vegetation period. The presence of $\mathrm{Pb}, \mathrm{Zn}, \mathrm{Ni}, \mathrm{Cu}, \mathrm{Cd}, \mathrm{Mn}, \mathrm{Cr}, \mathrm{Fe}$ and $\mathrm{As}$, in the samples were analyzed using Inductively Coupled Plasma-Atomic Emission Spectrometry (ICP-AES). Measurements of heavy metal contents were performed at three locations in soil and vegetative parts of three-plant types (plant alimentary) period during summer. The plant samples from the immediate environment of the dumpsite were highly contaminated with $\mathrm{Zn}, \mathrm{Cd}$ and $\mathrm{Mn}$. Three plants species: grape, artichoke and pepper, particularly, grape met some of the conditions to be classified as accumulators for $\mathbf{Z n}, \mathbf{C u}, \mathbf{C d}$ and $\mathbf{F e}$, consequently, she revealed a health risk for human and livestock due to the spread of the metal pollution from waste dumpsites to agricultural areas.
\end{abstract}

Key words: Pollution, Heavy metals, Contaminant, Industrial effluent and Agricultural soil

\section{INTRODUCTION}

The term 'heavy metal' is often used to cover a diverse range of elements, which constitute an important class of pollutants. With the industrial development, the production and emission of heavy metals have increased. Some metals, e.g. $\mathrm{Mn}, \mathrm{Cu}, \mathrm{Zn}, \mathrm{Mo}$ and Ni, are essential or beneficial micronutrients for microorganisms, plants, and animals, but at high concentrations all these metals have strong toxic effects and pose an environmental threat. ${ }^{1}$

Heavy metal pollution can be defined as an undesirable change in the physical, chemical or biological characteristics of land, water and air, that may or will harmfully affect animals and plants. ${ }^{2}$ Heavy metals have received the attention of researchers all over the world, mainly due to their harmful effects on plants, especially those on vegetative and generative parts of the plants. ${ }^{3}$

The presence of heavy metals in different foods constitutes serious health hazards, depending on their relative levels. For example, cadmium and mercury injure the kidney and cause symptoms of chronic toxicity, including impaired kidney function, poor reproductive capacity, hypertension, tumors and hepatic dysfunction. ${ }^{4,5}$ Lead causes renal failure and liver damage. ${ }^{4}$ Some other metals (e.g. chromium, zinc and copper) cause nephritis, anuria and extensive lesions in the kidney. ${ }^{4}$ Therefore, the problem of food contamination (including fish) by toxic metals is receiving global attention.

Soil adjacent to the industrial area contains the highest concentration of heavy metals. Among heavy metals, lead and cadmium are not essential elements for plants and are generally of low availability in soils, ${ }^{7,6}$ investigated the cadmium and lead uptake grown in three different textured soils and found $\mathrm{Cd}$ and $\mathrm{Pb}$ concentration in plant parts were highly correlated with $\mathrm{Cd}$ and $\mathrm{Pb}$ application, respectively. Similarly, the essentiality of chromium for plants has not been demonstrated, ${ }^{8}$ whereas the importance of nickel has been documented by a few scientists. ${ }^{9,10}$ Zinc and iron are essential nutrients for plants. ${ }^{7}$ The heavy metals of most concern are cadmium and zinc, as these show great mobility in the soil environment. ${ }^{11}$

There are no studies about the pollution of alzinc ursine second in Africa continental after South Africa of production the zinc metal, so far. Therefore, this study assesses the pollution effects of heavy metals on agricultural soils and plant alimentary at Ghazaouet. Heavy metal, $\mathrm{Pb}, \mathrm{Zn}$, $\mathrm{Ni}, \mathrm{Cu}, \mathrm{Cd}, \mathrm{Mn}, \mathrm{Cr}, \mathrm{Fe}$ and As were examined in different plants species alimentary. The objectives of the present study were (i) to characterise the fate and dispersal of $\mathrm{Pb}$, $\mathrm{Zn}, \mathrm{Ni}, \mathrm{Cu}, \mathrm{Cd}, \mathrm{Mn}, \mathrm{Cr}, \mathrm{Fe}$ and $\mathrm{As}$ in soils around a former 
mining area, (ii) to measure $\mathrm{Pb}, \mathrm{Zn}, \mathrm{Ni}, \mathrm{Cu}, \mathrm{Cd}, \mathrm{Mn}, \mathrm{Cr}$, Fe and As levels in the three plant alimentary (artichoke, grape and pepper) and (iii) determination the rate risk of health man et animals. In summary, we address an initial strategy to waste dumpsite risk in this site that also takes into account the presence of significant concentrations of heavy metals.

\section{MATERIALS AND METHODS}

\section{Sampling Location}

The field study site was located in an agricultural area, where the most common vegetable grown at all the study sites are grape, pepper and artichoke, situated in Ghazaouet (longitude W $01^{\circ} 52^{\prime} 21$, latitude N 35 $06^{\prime} 00$ ), exactly $1 \mathrm{~km}$ from the discharge site and 2,5 km from industrial site of essence (Fig. 1). Soils and plants were sampled in the surrounding of the dumpsite around $200000 \mathrm{~m}^{2}$. Sampling was collected out between June 2007 and July 2008. Shoots of several plant species were collected, as well as representative soil samples from the soil directly adjacent to the sampled plants (0-20 cm, topsoil layer), obtaining a total of 3 soil samples and 3 plants samples. Three regions

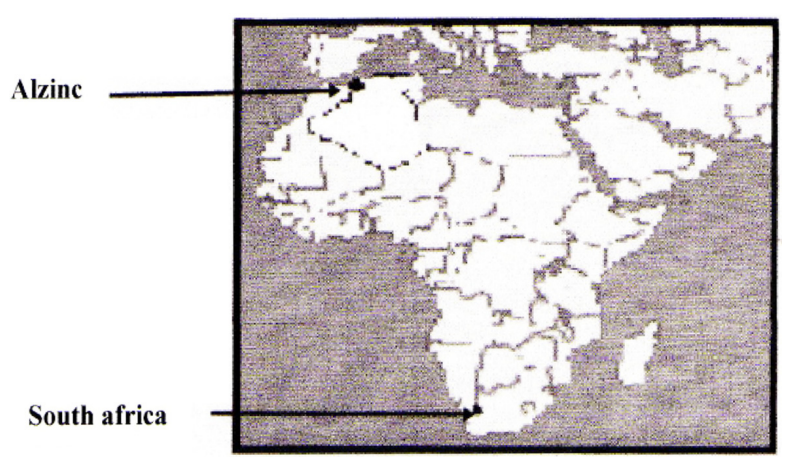

Fig. 1. location of alzinc ursine, Ghazaouet. Algeria. were identified:

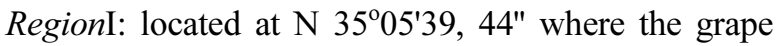
grown; Region II: located at N 35 $05^{\prime} 25,04^{\prime \prime}$ where the artichoke grown and Region III: located at 35 $05^{\circ} 21,67^{\prime \prime}$ where the pepper grown.

\section{Plant and soil samples pre-treatment}

For better preparation against contamination during sampling, soil were collected with plastic spatulas and stored in polypropylene boxes. After collection, pebbles and twigs were removed. All soil samples were taken by mixing six sub-samples from three sites of each plot at 0-20 cm depth. Each soil sample was air-dried and sieved to $<2 \mathrm{~mm}$ for physico-chemical properties including $\mathrm{pH}$, potassium $(\mathrm{K})$, calcium $(\mathrm{Ca})$, magnesium $(\mathrm{Mg})$, sodium $(\mathrm{Na}), \mathrm{CaCO}_{3}$, organic matter, total organic, heavy metals. Total K, Ca, Na and Mg concentrations were determined using flame emission after digestion of the composite samples with boiling $2 \mathrm{M} \mathrm{HNO}_{3}$ for $2 \mathrm{~h}$.

The methods of analysis used are presents in Table 1, vegetable and soil samples were taken randomly across the field during summer June 2008, near from potential contamination Sources (industrial plants, busy roads, residential areas, etc.). Plant samples collected from the field were washed under running tap water to remove adhered soils.

The metal analyses of samples $(\mathrm{Cu}, \mathrm{Fe}, \mathrm{Zn}, \mathrm{Mn}, \mathrm{Cr}, \mathrm{Pb}$, $\mathrm{Cd}, \mathrm{Ni}$ and $\mathrm{As}$ ) were carried out by using an Inductively Coupled Plasma-Atomic Emission Spectrometry standard reference (HISS-1, MESS-3 and PACS-2). The concentrations of heavy metals are expressed as $\mathrm{mg} / \mathrm{kg}$ dry weight. The absorption wavelengths were $193.696 \mathrm{~nm}$ for As: $205.560 \mathrm{~nm}$ for $\mathrm{Cr}: 324.754 \mathrm{~nm}$ for $\mathrm{Cu}: 259.940 \mathrm{~nm}$ for Fe: $257.610 \mathrm{~nm}$ for Mn: $216.555 \mathrm{~nm}$ for Ni: $220.353 \mathrm{~nm}$ for $\mathrm{Pb}: 213,857 \mathrm{~nm}$ for $\mathrm{Zn}$ and $214.439 \mathrm{~nm}$ for $\mathrm{Cd}$, respectively.

Table 1. Methods of analysis the soil and the plant

\begin{tabular}{|c|c|c|}
\hline Measure & Principe & Method \\
\hline Residual moisture content & Weighing the test portion before and after heating at $105^{\circ} \mathrm{C}^{*}$ & NF ISO 11465 \\
\hline Organic carbon & Dry combustion or sulfo-chromic acid oxidation (when $\mathrm{CaCO}_{3} \mathrm{~N} 50 \mathrm{~g} \mathrm{~kg}^{-1}$ ) ${ }^{*}$ & $\begin{array}{l}\text { NF ISO } 10694 \\
\text { NF ISO } 14235\end{array}$ \\
\hline Total carbonate & Measurement of the volume of $\mathrm{CO}_{2}$ released after reaction with $\mathrm{HCl}^{*}$ & NF ISO 10693 \\
\hline $\mathrm{pH}$ & $\mathrm{pH}$ of a water suspension, ${ }^{* * *}$ & NF ISO 10390 \\
\hline $\begin{array}{l}\text { Total } \mathrm{Cd}, \mathrm{As}, \mathrm{Mo}, \mathrm{Cr}, \mathrm{Cu} \\
\mathrm{Mn}, \mathrm{Mo}, \mathrm{Ni}, \mathrm{Pb} \text { and } \mathrm{Zn}\end{array}$ & $\begin{array}{l}\text { Determined by ICP-AES after Digestion of the samples with aqua regia } \\
\text { (nitric-chloric acid }(1: 3 \mathrm{~V} / \mathrm{V}) \text { ) }\end{array}$ & NF ISO 11466 \\
\hline Electrical conductivity & water suspension with the ration $1: 5^{*}$ & NF ISO 11265 \\
\hline Organic matter & Calcinations at $550^{\circ} \mathrm{C}$ at $5 \mathrm{~h}$ in the four ${ }^{*}$ & NF ISO 10694 \\
\hline$\overline{\mathrm{CEC}}$ & Percolation of a $1.0 \mathrm{~mol} \mathrm{l-1}$ ammonium acetate solution, $\mathrm{pH}=7^{*}$ & NF X31-130 \\
\hline
\end{tabular}




\section{Analysis methods \\ Plant analysis}

The roots and sheets of the different plants were analyzed separately for heavy metal content. $1 \mathrm{~g}$ of $<2 \mathrm{~mm}$ fraction plant samples was weighed into porcelain crucibles and was ignited in a muffle furnace for $6 \mathrm{~h}$ at a temperature between $450-500{ }^{\circ} \mathrm{C}$. Grey white ash was obtained at the completion of the ashing. The ash samples were allowed to cool and then $10 \mathrm{ml}$ of $2 \mathrm{M}$ nitric acid $\left(\mathrm{HNO}_{3}\right)$ was added to each sample. The solution was evaporated to near dryness on a hot plate and the cooled residues were re-dissolved in $10 \mathrm{~mL} 2 \mathrm{M}$ nitric acid $\left(\mathrm{HNO}_{3}\right)$. The solutions were then filtered into $25 \mathrm{~mL}$ volumetric flasks. Both the crucible and the filter paper were washed into the flasks, made up with deionized water and then stored in polyethylene tubes for instrumental analysis. Inductively Coupled Plasma-Atomic Emission Spectrometry (ICPAES) standard reference (HISS-1, MESS-3 and PACS-2) was used to analyse soil, plant digests for ten heavy metals (Table 2) and the blanks were measured in parallel.

\section{Soil analysis}

The $<2 \mathrm{~mm}$ fraction soil samples were used to determine the maximal environmentally available heavy metals. This was done using aqua regia, ${ }^{12}$ samples were digested with a chlorhydric $(37 \%)$ and nitric $(70 \%)$ acids mixture in a ratio of $3: 1(\mathrm{v} / \mathrm{v})$, at room temperature for $16 \mathrm{~h}$ and, after, at $130{ }^{\circ} \mathrm{C}$ for $2 \mathrm{~h}$, under reflux conditions. Each suspension was then filtered, diluted to $100 \mathrm{ml}$ with $0.5 \mathrm{M}$ nitric acid and stored at $4{ }^{\circ} \mathrm{C}$ until analysis.

\section{RESULTS AND DISCUSSION}

The nature of soil is characterized by several basic phys- ical, chemical and biological properties. The interrelationship between these properties determines the capabilities and limitations of the soil for plant growth. Thus the soil acts as a reservoir for plant nutrients. Not all the nutrients are present in plant available form. Some are components of rock minerals or organic compounds that must be simplified before they can be utilized by the plant. If all the nutrients are present in adequate amounts, the plant should exhibit good growth and vigor. ${ }^{11,13}$ However soils are affected by the geology of substrate, trampling by activity of ursine and addition of pollutants from automobiles.

In the present study, it was found The $\mathrm{pH}$ of the soils ranged between moderately acidic 5.10 and slightly alkaline 8.66. The levels of $\mathrm{Na}, \mathrm{K}, \mathrm{Ca}$ and $\mathrm{Mg}$ were much lower in the wastes dumpsite alzinc when compared with their high levels in adjacent soils (Region I, II and III). The amount of organic matter and total nitrogen is median, Soil reaction or $\mathrm{pH}$ is a simple and direct measure of the overall chemical condition of soils. ${ }^{14}$ It has been found that soil $\mathrm{pH}$ is correlated with the solubility of nutrient compounds and hence their availability to the plant. Similarly it commonly recognized that at $\mathrm{pH} 6.5$, nutrient availability to plants is at highest and toxicity at the lowest. The $\mathrm{pH}$ of soil in the study area ranges from 7.39-8.66 with mean value of 8.1. This $\mathrm{pH}$ value also favors the widest range of soil organisms and their activities. ${ }^{15}$

Organic matter is needed for the chemical well being of the plant and soil fertility status because it is the source of nearly all the nitrogen and most of the phosphorus in some soils. ${ }^{13}$ In the present study organic matter showed 2.78$5.92 \%$, but addition of organic matter can markedly increase soil productivity by providing essential plant nutrients and by improving the physical properties of the soil. This

Table 2. Chemical composition of soils study

\begin{tabular}{|c|c|c|c|c|}
\hline \multirow{3}{*}{$\begin{array}{l}\text { Parameter } \\
\mathrm{pH}\end{array}$} & \multicolumn{4}{|c|}{ Study site } \\
\hline & \multicolumn{4}{|c|}{ Region I Region II Region III Dumpsite } \\
\hline & 8.48 & 7.39 & 8.66 & 5.10 \\
\hline Electrical conductivity $\left(\mathrm{ms} . \mathrm{Cm}^{-1}\right)$ & 0.414 & 0.623 & 0.544 & 0.234 \\
\hline Organic matter $(\%)$ & 2.78 & 5.92 & 2.94 & 1.23 \\
\hline $\mathrm{CaCO}_{3}\left(\mathrm{~g} \mathrm{~kg}^{-1}\right)$ & 4.80 & 5.68 & 5.25 & 4.05 \\
\hline Organic-C $\left(\mathrm{g} \mathrm{kg}^{-1}\right)$ & 1.70 & 3.64 & 1.63 & 1.05 \\
\hline Total-N ( $\left.\mathrm{g} \mathrm{kg}^{-1}\right)$ & 0.89 & 1.12 & 0.67 & 0.23 \\
\hline $\mathrm{CEC}\left(\mathrm{cmol}^{+} \mathrm{kg}^{-1}\right)$ & 29.13 & 32.94 & 30.15 & 22.34 \\
\hline Sodium $(\mathrm{Na})\left(\mathrm{g} \mathrm{kg}^{-1}\right)$ & 2.94 & 1.19 & 0.53 & 0.12 \\
\hline Potassium $(\mathrm{K})\left(\mathrm{g} \mathrm{kg}^{-1}\right)$ & 8.38 & 2.37 & 1.18 & 1.03 \\
\hline Calcium $(\mathrm{Ca})\left(\mathrm{g} \mathrm{kg}^{-1}\right)$ & 150.11 & 55.11 & 47.61 & 6.43 \\
\hline Magnesium $(\mathrm{Mg})\left(\mathrm{g} \mathrm{kg}^{-1}\right)$ & 17.43 & 2.45 & 1.43 & 0.73 \\
\hline
\end{tabular}

Region I: $40 \mathrm{~mW}$; Region II: $100 \mathrm{~mW}$ and Region III: $200 \mathrm{mWS}$ of dumpsite of alzinc ursine (W: west and WS: South-West) 
moderate amount of organic matter in present study is supported by the fact that $\mathrm{pH}$ will be higher where organic matter is well decomposed and incorporated into the surface mineral horizon. ${ }^{13}$ The amount of organic matter maintained in any soil is largely dependent on the amount of nitrogen present. The ratio between the nitrogen and organic matter is, thus, also rather constant ${ }^{14}$ states that organic matter contents in soil cannot be increased without simultaneously increasing its nitrogen contents and vice versa.

The other macronutrients essential for plant growth, potassium, calcium and magnesium were present in adequate amount, Among them, calsium was present in slightly higher amount i.e. value of 47.61-150.11 g/ $\mathrm{kg}$ (Table 2), but The levels of $\mathrm{Na}, \mathrm{K}, \mathrm{Ca}$ and $\mathrm{Mg}$ were much lower in the dumpsite of alzinc when compared with their high levels in adjacent soils (Region I, II and III).

Heavy metals are chemical elements common to all types of soils, and their abundance ranks between percentage (iron only) and parts per million. The very low general level of their content in soil and plants, as well as the biological role of most of these chemical element, has led them being grouped under the generic name of 'micro elements', when the soil has very high content of such chemical elements, the term 'heavy metal pollution' is used. Hence heavy metals are synonyms to pollution and toxicity. ${ }^{11,16}$ The determination of heavy metals in soils was carried out for the measurement of the total element content and to assess the base line knowledge of soil components with respect to which changes in soil composition produced by vehicular pollution and agricultural inputs in the surrounding fields.

Soil contamination by heavy metals is increasing nowadays, ${ }^{17}$ in the present study, the heavy metals $(\mathrm{Pb}, \mathrm{Zn}, \mathrm{Ni}$, $\mathrm{Cu}, \mathrm{Cd}, \mathrm{Mn}, \mathrm{Cr}, \mathrm{Fe}$ and $\mathrm{As}$ ) concentration with the exception of iron, decreased with the increase in distance from the road, i.e. from the border zone to the verge zone.

\section{Distribution of heavy metals in soils}

The highest levels of $\mathrm{Zn}, \mathrm{Cd}, \mathrm{Mn}$ and Fe were found in the composite soil from adjacent of the waste dumpsite the alzinc industrial area indicating the waste as the source of soil pollution and contamination (Table 3). All the soil samples collected of the waste dumpsite had lower levels of $\mathrm{Pb}$ than the normal cleanup level of $\mathrm{Pb} 400 \mathrm{mg} / \mathrm{kg}$ in soils (Table 4). The levels of $\mathrm{Zn}$ were inside the range found in contaminated soils $20-300 \mathrm{mg} / \mathrm{kg}$. The levels of $\mathrm{Ni}$ found in the soil samples were within the normal range of $1-110 \mathrm{mg} / \mathrm{kg}$ reported for uncontaminated soils.

The copper, chromium and arsenic concentrations were, however, lower than the values reported for typical uncontaminated soil $50-150 \mathrm{mg} / \mathrm{kg}, 150 \mathrm{mg} / \mathrm{kg}, 40 \mathrm{mg} / \mathrm{kg}$ (Table 4). The high metal concentrations of the soil could have negative effects on microbial activities, ${ }^{20}$ provoking a low organic matter mineralization during the plant growth.

The apparent diminishing of heavy metals concentration away from the waste dumpsite of alzinc almost certainly confirms the waste as the potential source of soil contamination and their concentrations in plants. Samples of plant collected from the immediate environment of

Table 4. Doorstep toxic of heavy metals in soil and plant ${ }^{18,19}$

\begin{tabular}{lcc}
\hline & \multicolumn{2}{c}{ Threshold values (mg/kg dry weight) } \\
\cline { 2 - 3 } & [Metal] in plant & [Metal] in soil \\
\hline Lead $(\mathrm{Pb})$ & 50 & $100-400$ \\
Zinc $(\mathrm{Zn})$ & $100-400$ & $20-300$ \\
Nickel $(\mathrm{Ni})$ & $1-5$ & $1-100$ \\
Copper $(\mathrm{Cu})$ & 20 & $50-100$ \\
Cadmium $(\mathrm{Cd})$ & $0.01-1$ & $1-3$ \\
Manganese $(\mathrm{Mn})$ & 60 & 60 \\
Chromium $(\mathrm{Cr})$ & $0.5-2$ & 150 \\
Arsenic $(\mathrm{As})$ & $3-10$ & 40 \\
Iron $(\mathrm{Fe})$ & $500-1500$ & 1000 \\
\hline
\end{tabular}

[Metal]: concentration of metal

Table 3. Concentration of heavy metals in soils and plants collected from waste dumpsite of alzinc ursine

\begin{tabular}{lcccccc}
\hline \multirow{2}{*}{ Experimental results } & \multicolumn{2}{c}{ Region I } & \multicolumn{2}{c}{ Region II } & \multicolumn{2}{c}{ Region III } \\
\cline { 2 - 7 } & Soil & Grape & Soil & Artichoke & Soil & Pepper \\
\hline lead $\left(\mathrm{mg} \mathrm{kg}^{-1}\right)$ & 39.14 & 16.61 & 17.81 & 28.47 & 7.99 & 5.42 \\
Zinc $\left(\mathrm{mgkg}^{-1}\right)$ & 21.15 & 918.89 & 731.08 & 887.97 & 432.15 & 1581.66 \\
Nickel $\left(\mathrm{mg} \mathrm{kg}^{-1}\right)$ & 10.07 & 18.58 & 15.31 & 15.88 & 14.37 & 19.65 \\
Copper $\left(\mathrm{mgkg}^{-1}\right)$ & 15.32 & 38.14 & 6.00 & 39.22 & 4.32 & 44.97 \\
Cadium $\left(\mathrm{mg} \mathrm{kg}^{-1}\right)$ & 10.18 & 3.42 & 4.18 & 2.24 & 1.89 & 6.15 \\
Manganese (mg kg-1) & 244.94 & 73.72 & 92.00 & 56.52 & 79.03 & 81.36 \\
Chronium $\left(\mathrm{mg} \mathrm{kg}^{-1}\right)$ & 73.32 & 48.26 & 22.05 & 33.62 & 17.87 & 8.64 \\
Iron $\left(\mathrm{mg} \mathrm{kg}^{-1}\right)$ & 9390 & 400 & 5410 & 1690 & 4030 & 220 \\
\hline Arsenic $\left(\mathrm{mg} \mathrm{kg}^{-1}\right)$ & 37.19 & 26.17 & 3.08 & 2.20 & 4.92 & 3.83 \\
\hline
\end{tabular}


the waste were grossly contaminated with $\mathrm{Zn}, \mathrm{Mn}$ and $\mathrm{Cd}$. The high levels of these metals present the site as potentially hazardous and highly inimical to food chain and biological life in the environment. This makes remediation of the site a matter of urgency for safe biological life and for a clean environment.

\section{Heavy metals accumulation in plants}

The results obtained showed that heavy metal concentrations in the plants varied with plant species, levels of heavy metals in the soils and heavy metal contaminants.

The Various studies have shown heavy contamination of agricultural soils and vegetation with lead concentration declining steeply with distance from the road, ${ }^{21}$ as was seen in the present study. The rate of lead deposition to the ground is very much dependent upon the presence and nature of vegetation. The rate of deposition of lead on grass is about four times greater than on bare soil. ${ }^{22}$ In the present study the lead concentration in three plant alimentary recorded was quite low than national environmental quality standard range i.e. $50 \mathrm{mg} / \mathrm{kg}$. However, when values were expressed on a fresh weight basis, the limit established by the European Union for leaf vegetables in foodstuff $0.3 \mathrm{mg} / \mathrm{kg} .{ }^{23}$

Zinc is essential element for plant growth, as it serves an important role in plant structure and function, ${ }^{11}$ it is a natural constituent of soils in terrestrial ecosystem. It usually occurs in low concentrations and does not pose a toxicity problem for plants, ${ }^{24}$ but increased concentrations of zinc in soil can lead to toxic effects in plants. ${ }^{25}$ Potentially toxic quantities of zinc in soil result largely from anthropogenic (soil located near dumpsite) sources. In Table 3, the value of zinc in study plant, grape, artichoke and pepper was $918.89,887.97$ and $1581.66 \mathrm{mg} / \mathrm{kg}$. These values of zinc were quite high as compared to national environmental quality standard range i.e. $100-400 \mathrm{mg} / \mathrm{kg} .{ }^{11}$

Nickel plays an essential role in metabolic processes of higher plants, ${ }^{11}$ the value of nickel in study plant: grape, artichoke and pepper was $18.58,15.88$ and $19.65 \mathrm{mg} / \mathrm{kg}$, respectively. These values of nickel were quite high as compared to national environmental quality standard range i.e. $1-5 \mathrm{mg} / \mathrm{kg}$. ${ }^{11}$ Copper concentrations in plants species were higher than the toxic values $20 \mathrm{mg} / \mathrm{kg}{ }^{26}$

Cadmium is yet not known to have any biological function on the contrary, is said to be highly toxic to plants and animals. ${ }^{11}$ Compared with the other metals cadmium is more mobile in soil in relation to both leaching and availability to plants. ${ }^{11,23}$ The value of grape, artichoke and pepper was 3.42, 2.24 and $6.15 \mathrm{mg} / \mathrm{kg}$, respectively, where
$\mathrm{Cd}$ content is high. These values indicate quite coherence with national environmental quality standard range i.e. $0.1-1 \mathrm{mg} / \mathrm{kg} .{ }^{27}$ It has also been found that cadmium pollution without co-contamination by zinc is rare. ${ }^{25}$ Similarly (Berthelsen et al. $)^{28}$ found that spatial pattern of cadmium level in vegetation was analogous to that of zinc.

Mn concentrations greater than $60 \mathrm{mg} / \mathrm{kg}$ in grape and pepper can be considered high in plants, but is low in artichoke (Table 3). ${ }^{26}$ The concentrations of Mn in both plant species were in excess of the threshold micronutrient concentration in animal feeds $>70 \mathrm{mg} / \mathrm{kg}^{26,29}$

Although the essentiality of chromium for plants has not been documented however, few studies have shown the importance of nickel in soil for plants, but nickel is more likely to be toxic than the relatively large concentration of chromium. ${ }^{30}$ the value of chromium $48.26,33.62$ and $8.64 \mathrm{mg} / \mathrm{kg}$ in grape, artichoke and pepper, respectively. The present study indicates a fairly-high level in the study area. Among the heavy metals, chromium is commonly identified soil contaminant. It is ubiquitous environmental pollutant and is phototoxic at very low concentrations, but still this value can cause toxicity to the soil and plants because the toxic range was $0.5-2 \mathrm{mg} / \mathrm{kg}$. ${ }^{11,26}$

Arsenate mobility in soils is governess by the presence
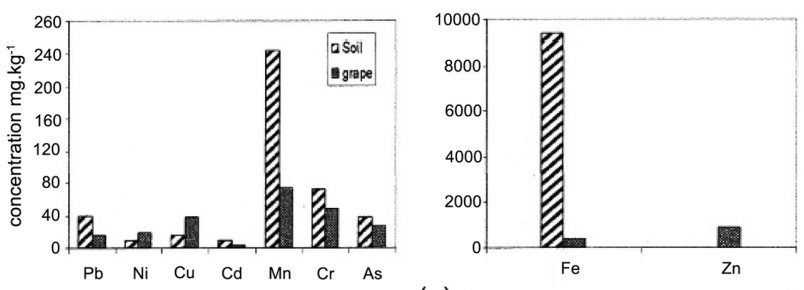

(a)
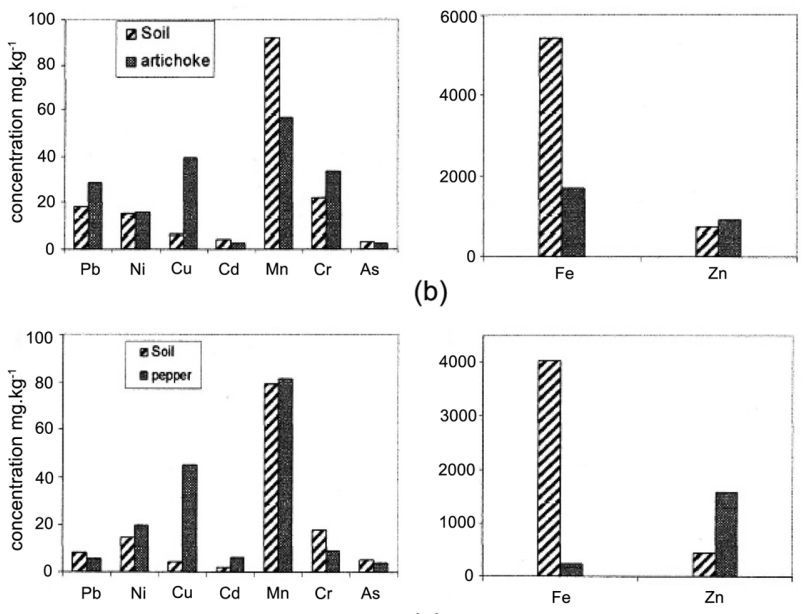

(c)

Fig. 2. Heavy metal concentration in (a) Region I (soi land grape); (b) Region II (soil and artichoke); (c) Region III (soil and pepper). 
of iron and manganese hydroxides, organic matter, $\mathrm{pH}$, and phosphate. Arsenic in plants artichoke and pepper is usually below the toxicity threshold for aboveground tissues of 3-10 $\mathrm{mg} / \mathrm{kg}$ dry weight, but is very high at grape $26.17 \mathrm{mg} / \mathrm{kg} .{ }^{18,25}$

\section{CONCLUSION}

This site presents three potential hazards that need to be remediated by soil amendments and site phytostabilisation. In this context, the area should be carefully monitored in order to detect changes in the long-term risk due to the presence of elevated concentrations of trace elements in soils. Toxicological tests and risk assessment will also be carried out with highly polluted soils from this site to evaluate the actual environmental risk of trace elements and their transfer to the food chain. The grape plant alimentary behaved as a metal indicator for $\mathrm{Mn}, \mathrm{Cu}, \mathrm{Cr}$ and $\mathrm{Cd}$, indicating that it can be used for testing changes in metal availability in soils. The concentrations of metals in both plant species exceeded the limits established for humans and grazing an animal, which implies a health risk linked with the spread of the pollution from mining sites to agricultural areas.

Acknowledgements. In this work, I grateful the laboratory of analyse of metal trace of alzinc ursine, Ghazaouet, and their cooperation for all information reported about this study.

\section{REFERENCES}

1. Nodelkoska, T. V.; Doran, P. M. Environ. Pollut. 2000, 107, 315 .

2. Odum, E. P. Fundamentals of Ecology, 3th ed.; Saunders: Philadelphia, 1971; p 574.

3. Ekatarina, A.; Jeliazkova, L. E. University of Massachusetts, Amherst, MA, U.S.A, An internet review. 2001.

4. Luckey, T. D.; Venugopal, B. Plenum Press: New York, 1977.

5. İsmail, K.; Selda, T. Ö.; Murat, B. Fresenius Environmental Bulletin 2006, 15(1), 26.

6. Kibria, M. G.; Osman, K. T.; Ahmed, M. J. Soil and Envi- ronment 2007, 26(2), 106.

7. Fredeen, A. L.; Pugh, R. E.; Dick, D. G. Ecotoxicol. Environ. Saf. 2002, 52(3), 273.

8. Guthrie, B. E. Elsevier, Amsterdam. 1982, 117, 148.

9. Dixon, N. E.; Gazzola, C.; Blakely, R. L.; Zerner, B. J. Am. Chem. Soc. 1975, 97, 4131.

10. Brown, P. H.; Welch, R. M.; Cary, E. E. Plant Physiol. 1987, 85, 801.

11. Ahmad, S. S.; Erum, S. Soil and Environment 2010, 29(2), 110.

12. Pueyo, M.; Sastre, J.; Hernández, E.; Vidal, M.; LópezSanchez, J. F.; Rauret, G. J. Environ. Qual. 2003, 32, 2054.

13. Craul, P. J. John Wiley \& Sons: New York, 1992.

14. Brady, N. C. The Nature and Properties of Soils, 11th ed.; McMillan: New York, 1996; p 621.

15. Alexander, M. Plenum Press: New York, 1980; p 363.

16. Hodson, M. E. Environ. Pollut. 2004, 129, 341.

17. Lin, C.; Lin, H. J. Hazard. Mater. 2005, 122(1-2), 7.

18. Eduardo, M. J.; Rebeca, M.; Elvira, E.; Jesús, P. J. Soils and Sediments 2010, 10, 301.

19. Alvarenga, P.; Palma, P.; Gonçalves, A. P.; Fernandes, R. M.; Cunha-Queda, A. C.; Duarte, E.; Vallini, G. J. Environment International 2006, EI-01553, 9.

20. Dai, J.; Becquer, T.; Rouiller, J. H.; Reversat, G.; Reversat, F. B.; Lavelle, P. Applied Soil Ecology 2004, 25, 99.

21. Little, P. E. Environmental and Medical Services Division, A. E. R. E., Didcot, Oxford Shire, U.K., 1995.

22. Little, P.; Wiffenn, R. D. Atmos. Environ. 1978, 12, 1331.

23. Commission of the European Communities, 2001. Commission Regulation (EC) No. 466/2001, 8 March 2011. setting maximum levels for certain contaminants in foodstuffs, Official J. Eur. Commun. L77 of 16/3/2001.

24. Paschke, M. W.; Redente, E. F.; Levy, D. B. Environmental Toxicity and Chemistry 2000, 19, 2751.

25. Chaney, R. L.; Oliver, D. P. In Contaminants and the Soil Environment in the Australia-Pacific Region; R. Naidu et al., Eds.; Kluwer Academic Publishers: Dordrecht, 1996; p 259.

26. Clemente, R.; Paredes, C.; Bernal, M. P. Agriculture, Ecosystems and Environment 2007, 118, 319.

27. Blake, L.; Goulding, K. W. T. Plant and Soil 2002, 240, 235.

28. Berthelsen, B. O.; Steinnes, W.; Jingsen, L. J. Environ. Qual. 1995, 24, 1018.

29. Georgievskii, V. I.; Annenkov, B. N.; Samokhin, V. T. Mineral Nutrition of Animals; Butterworths: London, 1982.

30. Brooks, R. R. Serpentine and Its Vegetation; Croom Helm: London, 1987. 